\title{
THE USE OF HUMAN RIGHTS INSTRUMENTS TO PROTECT THE VICTIMS OF LAND FIRE IN INDONESIA
}

\author{
Achmad Romsan, Akhmad Idris, Mada Apriandi Zuhir, Meria Utama \\ Faculty of Law, Universitas Sriwijaya (UNSRI), South Sumatra, Indonesia \\ Email: aromsan@yahoo.com; meriautama@yahoo.co.id
}

\begin{abstract}
During the long and dry season, land fire which cause smog haze pollution, is a common phenomenon in Indonesia. Although the practice of slash and burn cultivation has no longer in existence after the promulgation of Law Number 5 of 1974 on the Village Government which abolished the Marga Government. Nevertheless, that tradition remained continued practiced by the workers hired by the big palm plantation companies and industries when they open the land to start their activities. it is very surprising that the above practice has resurfaced in the midst of a long dry season that is happening in Indonesia, especially in South Sumatra. Smog and haze resulting from land fire create health problems for the people in South Sumatra, especially in the area where smog and haze located. There are legal instruments as the foundation to claim the healthy environmental rights, the 1945 Constitution of The Republic of Indonesia, Law Number 32 of 2009 on Human Rights and Law Number 32 of 2009 on the Environmental Protection of and the Environmental Management. Herein, the smog and haze pollution are seen to violate the people's human rights. Unfortunately, the use of human rights law instruments has never been done in Indonesia. Notwithstanding, many community environmental disputes are brought to the District Court rather than to the Indonesian Commission of Human Rights (hereinafter referred to KOMNAS HAM) for further study. As a result, the legal instruments above di not fully protect the victims of environmental pollution. This paper suggests the use of human rights provisions as the basis for prosecution for community environmental-human rights related disputes. For that, a comparative study to the practice of the European Human Rights Court will be of beneficial for Indonesia in protecting the people environmental human rights. In Indonesia the people's right to a good and healthy environment is constitutional rights and legal rights for it is protected in Law Number 39 of 1999 on the Human Rights and Law Number 32 of 2009 on The Environmental Protection .To that end, the human rights approach to the prosecution of environmental disputes are possible because of environmental pollution disturb the enjoyment of human rights.
\end{abstract}

Key words: forest fire, land fire, smog and haze pollution, environmental degradation, civil suit.

584 Yustisia Vol. 7 Number 3 (Sept.-Dec. 2018) Juridical Analysis Of The Working ...

(C2018; This is an Open Acces Research distributed under the term of the Creative Commons Attribution Licencee (https://Creativecommons.org/licences/by/4.0), which permits unrestricted use, distribution, and reproduction in any medium, provided the original works is properly cited. 


\section{A. INTRODUCTION}

Land fire is a yearly environmental problem always occurs during the long dry season in Indonesia, especially in the low land areas of South Sumatra, Jambi, Riau and Kalimantan. The dry season begins in the month of March and last at the end of September, the month in which the peasants in South Sumatra start to cut and slash and burn the trees and the bushes. Furthermore, end of September is the first month of entering the period of raining season (Ketterings, at al, 1999: 157-169) where the peasants begin to open the land for growing paddy. The slash and burn cultivation, according to Kleinman (P.J.A. Kleinmn, et al, 1995: 235-249) does not depend upon outside inputs, like fossil energy for fertilizers, pesticide and even irrigation. From economic perspective the tradition above is cheap means for the peasants to clear the forest land for agriculture (Anshuman Varma, 2003: 159-171). There are five advantages the peasants will get from the practice of slash and burn, burning created space; ash acted as fertilizer, burning improved soil structure enabling faster establishment of seedlings, burning reduced weed/trees competition and burning reduced the occurrence of pest/diseases (Quirine M. Ketterings, Titus Tri Wibowo, Meine van Noordwijk, and Eric Penot, 1999: 157-169). Overall, the practice of the slash and burn is cheap and fast. The peasants had this tradition through generations. On the contrary, the environmentalists argue that the slash and burn used in agriculture is not good for the environment.

The slash and burn cultivation in the Province of South Sumatra, theoretically, has no longer in existence. As the Marga's land area includes the Marga forest land had been converted to be the state's land and the state forest areas (see Law Number 5 of 1974 on the Village Government). Thenceforward, many investors came to South Sumatra to open the land for their business activities. The province of South Sumatra is one of the largest plam oil producer in Indonesia with an area of 866,763 hectares with a total production of fresh fruit bunches (FFB) produced in 2011 reaching around 2.11 million tons. Oil palm plantations in South Sumatra spead out in several districts and cities as illustrated in Table I. From table, one may see that the area of oil palm plantations in South Sumatra has reached $10.78 \%$ of the total area of Indonesian palm oil plantations with a total area of 8.04 million hectares. Meaning, oil palm plantations are the leading commodities sectors in South Sumatra. From this statement, one will understand that why the smog and haze pollution is an unending problem in South Sumatra. From the study conducted by Romsan (Achmad Romsan, Massive Forest Fire in South Sumatra toward the Fall of Suharto in 1997. Research Report in collaboration with Forest Fire Project funded by European Union in cooperation with the Department of Forestry of South Sumatra (Retrived, Oct 16, 2018)) using fire is cheap and fast for the workers only need a bottle of kerosine and a box of matches and the fire will do the job. Land fire is seen

\begin{tabular}{|l|l|l|}
\hline Yustisia Vol. 7 Number 3 (Sept.-Dec. 2018) & Juridical Analysis Of The Working ... & 585
\end{tabular} 
as crime against humanity (https://www.theguardian.com/sustainablebusiness/2015/ nov/11/indonesia-forest-fires-explained-haze-palm-oil-timberburning) since it hampered by seasonal dry conditions exacerbated by the El Nino effect. As well as Indonesia, the acrid haze from the fires is engulfing neighbouring Malaysia and Singapore and has reached as far as southern Thailand (https://www.theguardian. com/sustainable-business/2015/nov/11/indonesiaforest-fires-explained-haze-palm-oil-timber-burning).

Isyana Artharin (Isyana Artharin is an Indonesian BBC journalist, 24 Sept. 2015) is of the opinion that land fire in Indonesia is an organized crime. Furthermore Artharin declared that land clearing involved a lot of people who has different tasks. For instance, land claims, organized farmers who will slash or cut or burn the land, the person who will sell the land and the involvement of village apparatuses. The owner or landlords may be relatives of the villagers, the company's staff, the district employees, the businessman, or the medium scale investors from Jakarta, Bogor, or Surabaya. Each group who open the land will get paid based on the percentage which is between $51 \%-57 \%$ for the farmer organizer, for those who do the slash, cut and burn will get $2 \%-14 \%$. The price of the cleared land fields offered at a price of Rp. 8.6 million per hectare. For the land is in 'ready for planting' or has been burned is Rp11.2 million per hectare. Then three years later, after the land has been planted and ready for harvest, it can be sold at a price of Rp 40 million per hectare (BBC Indonesia, 24 September 2015). There is a lot of money involved in the business of land fire.

Table 1

Palm plantation area in South Sumatra in 2011

(South Sumatra Plantation Agency, 2011)

\begin{tabular}{llrrrrr}
\hline \multirow{2}{*}{ No. Districts/Cities } & \multicolumn{4}{c}{ Palm Companies } & Plantations & \multirow{2}{*}{ Total } \\
\cline { 2 - 5 } & & Companies & Nucleus/ha & Plasma(ha) & \\
\hline 1. & Musi Banyuasin & 55 & $148.462,55$ & $68.454,10$ & $22.395,00$ & $239.311,65$ \\
2. & OKI & 45 & $68.098,24$ & $58.368,73$ & $11.526,00$ & $137.992,97$ \\
3. & Banyuasin & 56 & $77.032,52$ & $27.048,65$ & $17.296,00$ & $121.377,17$ \\
4. & Musi Rawas & 22 & $58.662,19$ & $32.632,18$ & $37.535,00$ & $128.829,37$ \\
5. & Muaraenim & 22 & $58.594,74$ & $26.026,48$ & $25.057,00$ & $109.678,22$ \\
6. & Lahat & 8 & $29.439,58$ & $13.681,16$ & $6.796,00$ & $49.916,74$ \\
7. & OKU & 9 & $18.584,58$ & $24.159,30$ & $1.166,00$ & $43.909,88$ \\
8. & OKU Timur & 7 & $10.991,82$ & $5.562,71$ & $6.821,00$ & $23.375,53$ \\
9. & Ogan Ilir & 3 & $5.170,92$ & 0 & $2.876,00$ & $8.046,82$ \\
10. & Empat Lawang & 3 & $2.933,32$ & 0 & 117,00 & $3.050,32$ \\
11. & Prabumulih & 0 & 0 & 0 & $1.070,00$ & $1.070,00$ \\
12. & Lubuklinggau & 0 & 0 & 0 & 103,85 & 103,85 \\
13. & OKU Selatan & 0 & 0 & 0 & 101,00 & 101,00 \\
\hline & Total & 230 & $477.970,36$ & $255.933,31$ & $132.860,85$ & $866.763,52$ \\
& & & $(55,14 \%)$ & $(29,52 \%)$ & $(15,34 \%)$ & $(100,00 \%)$
\end{tabular}

586 Yustisia Vol. 7 Number 3 (Sept.-Dec. 2018) Juridical Analysis Of The Working ... 
Land fire in the province of South Sumatra, Riau and Central Kalimantan has attracted national and international attention for it occurred during the long dry season and suffered hundred thousand of people. In the civil law suit between the Minister for Environment and Forestry v. Pte Ltd: Bumi Mekar Hijau in 2015 (Letter of Decision of Forestry Minister Number S. 417/Mnhut-VI/2004. Through a Letter of Decision issued by the Head of Forest Planning Board the area is granted 122.500 hectare. The total area of forest land owned by Pte Ltd: BMH in the OKI District only is about 385.440 hectare of land) the Minister claim of compensation of Rp. 6.7 trillion for the forest land damage. Unfortunately, the Environment Minister has been defeated in the civil suit above (Decision Number 24/Pdt.G/2015/PN.Plg). The reason of the Court was that the civil suit submitted by the Minister was unclear or obscuur libel (Decision Number 24/Pdt.G/2015/PN.Plg.). On the contrary, in the second case was between the Minister for Environment and Forestry v. Pte Ltd: Waringin Agro Jaya (WAJ)(2015), the verdict of the South Jakarta Court granted the request of the plaintiff (the Minister for Environment and Forestry) that the defendant was responsible for the land fire covering the area of about 1.626 .53 hectare and paid compensation to the Minister of about Rp. 4.66 billion.

\section{B. PROBLEM STATEMENT}

The discussion in this article starting from the historical view of forest fire and land fire in the province of South Sumatra followed with the difficulty of identifying the actors behind the land fire. Since the pollution and environmental damage also violate the people's environmental human rights therefore the discussion moves to the issue of how to use the human rights instruments for environmental pollution and the possible submission to the Indonesian Commission of Human Rights. This article ends with conclusion.

\section{RESEARCH METHODS}

Based on the data that used and the nature of the juridical-normative research in this research applied statute approach. Data analysis conducted in qualitative technique by legal interpretation and synchronization of the provisions of the related law. Data gathering collected by library research to select the important part of Law on Human Rights and the Protection of and the Management of the Environment.

\section{DISCUSSION AND RESEARCH RESULTS}

\section{The Cause Of Forest Fire And Land Fire}

Actually, the phenomenon of land fire and forest fire has been the major problem in the province of South Sumatra when the traditional system of the

\begin{tabular}{ll|l|l}
\hline Yustisia Vol. 7 Number 3 (Sept.-Dec. 2018) & Juridical Analysis Of The Working ... & 587
\end{tabular} 
Marga government was still in existence. The traditional farmers, during the long dry season always opened the forest land for agricultural activities. The slash and burn cultivation was a method of clearing the land and it was regulated in the traditional customary law book named Simbor Cahaya (Law Number 4 of 1979 on the Village Government. See The Simbor Cahaya was a book of customary laws governing all of the life order of the indigenous people. This book was no longer applied after the system of Marga Government was replaced with the Village Government system in 1979). Herein, the Simbor Cahaya required that any member of the Marga community was obliged to ask for assistant from other member of the Marga Community when they started to open the land and used fire. Herein, fire break (sekat bakar) functioned as a method to prevent the spread of fire to other forest land area. The practice of slash and burn cultivation were only acknowledged and practiced in the low land areas of the District of Ogan Komering Ilir (OKI) and the District of Musi Banyuasin. Romsan (2000) reported in his study that the farmers started the slash and burn cultivation when the long and dry season (the Kemarau panjang) which was more than six months namely April -September (Achmad Romsan, CS, 2000)). The first rain in the month of October was the best period of planting the paddy rice and also the end of the smog and haze problems in South Sumatra.

Theoretically the practice of slash and burn cultivation vanished after the abolishment of Marga government in 1979. Nevertheless, the method above remained in used by the workers the company hired. Using fire is a cheap way to reduce the operational cost. The company only needs a bottle of kerosene and a box of matches to clear the land (Achmad Romsan CS, 1990).

\section{The Actors Behindland Fire}

Legally speaking, there is an Article regarding the "polluter pay principle" (See: Erwin Syahruddin, "Polluter Pays Principle (Prinsip Pencemarab Membayar)", in: https://www.academia.edu/2605231/Polluter_Pays_Principle_

Prinsip_Pencemaran_Membayar) in the Environmental Management Act (EMA 2009). This principle contains the obligation to pay the cost for environmental restoration to those who are proved to pollute the environment (EMA Number 32 of 2009). Criminal sanction to deter the polluters is also provided for in the EMAs as well (EMA Number 32 of 2009). Notwithstanding in reality, the principle above is hard to spell. Whilst the criminal provision in the EMAs is never been used. In massive forest fire in 1997 hampered in all parts of South Sumatra, the source of the fire one could not trace for the fire had spread everywhere. Finally, it was proven that herein the fire was used as weapon to abolish the border of the traditional land ownership which normally relied on natural demarcation

588 Yustisia Vol. 7 Number 3 (Sept.-Dec. 2018) $\quad$ Juridical Analysis Of The Working ... 
(Achmad Romsan, Massive Forest Fire in South Sumatra toward the Fall of Suharto in 1998. Research Report in collaboration with Forest Fire Project funded by European Union in cooperation with the Department of Forestry of South Sumatra.). There was an indication that the collaboration between the investors and the affluence people in Jakarta to use fire as a strategy to have the land at no cost (Achmad Romsan, Massive Forest Fire in South Sumatra Toward the Fall of Suharto in 1998). Romsan (Achmad Romsan, Massive Forest Fire in South Sumatra toward the Fall of Suharto in 1998. Research Report in collaboration with Forest Fire Project funded by European Union in cooperation with the Department of Forestry of South Sumatra) mentioned in his study that land fire in South Sumatra involved many stakeholders, the peasants, local people, government apparatuses, owner of the palm plantation, and industries. However, it is undeniable that the regulations can also be the trigger factor to cause land fire. For example, The Governor Regulation of the Central Kalimantan Number 15 of 2010 which authorize the Head of the Neighborhood Administration (RT/Rukun Tetangga) or the Headman (Lurah) or the Head of the Village (Kades/ Kepala Desa) to issues the permit to burn the forest land for a maximum of one hectare of land (http://www.dw.com/jd/penyebab-kebkranhutan-terungkap/a-18801135, retrieved 11 January 2016). The regulation above is now being revised after the forest fire disaster turned to cause haze calamity in all parts of Kalimantan. It is noted that Central Kalimantan and the low land of South Sumatra are characterized with huge peatlands areas (http://www.dw.com/jd/penyebab-kebkran-hutan-terungkap/a-18801135). Yet the actor behind the massive forest fire was remained unidentified.

After the reformation in Indonesia in 1998 which also as a sign of human rights and democracy, there were about 39 community environmental disputes brought before the district court(Achmad Romsan, 2015). Out of the number above, there were four famous cases attracted national and international attention, such as the Buyat Bay case (2004), the Lapindo volcano mudflow case in 2004 Pte Ltd: Lapindo Brantas, v. WALHI (2007), Verdict Number 284/Pdt.G/2007/ PN. Jak. Sel), the land fire caused by Pte Ltd: Bumi Mekar Hijau /BMH (Decision Number 24/Pdt.G/2015/PN.Plg.) and by Pte Ltd: Waringin Agro Jaya (WAJ) in the district of Ogan Komering Ilir (OKI) and Ogan Ilir of South Sumatra Province. Herein, even though the actors had been firmly identified but again the environmental justice of the people do not fully serve in the courts. According to Mas Achmad Santosa (Mas Achmad Santosa, Josi Khatarina and Rifqi Sjarief Assegaf, 2012: 178- 205) 'Judges in general tend to decide according to a strict interpretation of the letter of the law and only when the law is clear and explicit. They refrain from entertaining legal arguments that are based on the intent or

\begin{tabular}{|l|l|l}
\hline Yustisia Vol. 7 Number 3 (Sept.-Dec. 2018) & Juridical Analysis Of The Working ... & 589
\end{tabular} 
spirit of the law or general provisions in the law such as those that make reference to human rights- not to mention international principles or case law from other jurisdiction. Some judges take the position that general provisions of the law that require implementing regulations do not produce legal consequences until such regulations are passed.'

As a result, the court as the final frontier for justice is not able to serve the people with justice. The community environmental dispute involved many issues: poor people, large companies, the government, politicians, foreign intervention and environmental preservation and conservation. The decisions meted out by the courts were completely beyond expectation. For

example, in the Pte Ltd: Lapindo Brantas $v$ Walhi case the court declared that the hot volcano mudflow resulting from drilling activities in Porong Sidoarjo was a natural calamity (Verdict Number 284/Pdt.G/2007/PN.Jak. Sel). This court's decision was controversial because the court has ignored the opinions of both experts and the geologists that it was not natural disaster (Friends of the Earth International, 2007: 6). There was no connection between the earthquakes, which erupted within the radius of $300 \mathrm{~km}$ (186.5 miles) away from the main drilling site(Friends of the Earth International, 2007: 6) and the mud flow. It is noted in the mud flow case above, that a number of economic, social and economic rights had been impaired (Friends of the Earth International, 2007: 1-13).

In the Buyat (2007), there was no consensus amongst the research findings conducted either by the Sam Ratulangi University in Minahasa or the Ministry for Environment, or Pte Ltd: Newmont Minahasa Raya (NMR), the Provincial Government of North Sulawesi with regard to whether the Buyat Bay had been polluted by mercury, the heavy metal used by Pte Ltd: Newmont Minahasa Raya (NMR). From an environmental law point of view, the Buyat case is very complicated due to foreign political intervention that eventually affected the revocation of the case by the government. The Buyat case received the world's highest rating in 2007, a feat similar to that of the Minamata disease case in the Minamata Gulf Japan in 1958 (Kiki Lutfillah, 'Kasus Newmont (Pencemaran di Teluk Buyat),' page 26). On April 24, 2007, the President Director of The Pte Ltd: NMR was cleared of all charges relating to the alleged pollution in Buyat Bay. Furthermore, the Indonesian Court held that Buyat Bay was not polluted and that the Newmont's local subsidiary were in compliance with all environmental regulations and permits for the entirety of its operations from 1996 to 2004 (Kiki Lutfillah, 'KasusNewmont (Pencemaran di TelukBuyat), page 25). The very recent environmental disaster was land fire on the 1500 hectare of peatlands areas in the district of Ogan Komering Ilir, South Sumatra in 2015. The District Court Judge of Palembang has refused to grant the civil suit of the Minister for Environment and Forestry to Pte Ltd: Bumi Mekar Hijau (Pte Ltd: BMH) on

590 Yustisia Vol. 7 Number 3 (Sept.-Dec. 2018) Juridical Analysis Of The Working ... 
the ground that that the lawsuit was not clear or obscuur libels (Decision of the Palembang District Court Number 24/Pdt.G/2015/PN.Plg.). The statement made by the judge who handled the case when being interviewed by the journalists was "land fire does not deteriorate the environment since it can grow naturally." Besides that, he added that "Indonesians are stupid to understand one who has high education like him." "The factory cannot be blamed to cause environmental damage but the fire." That statement is of ridicule in social media for several months.

It is thus pertinent that the protection and the respect of environmental rights need to be implemented and not to be treated as a mere academic exercise. In Indonesia current mechanism within the judiciary are plagued with problems or constrains, namely the lack of jurisdiction in hearing environmental cases; the lack of independence from interferences; too time consuming; involve high cost and inevitably, a decision that may not be beneficial to any party or win-lose. The recourse via non-litigating alternatives such as mediation is available and may lead to a win-win solution but this mechanism is not yet popular among the disputants despite Indonesians being non-litigious people (Mas Achmad Santosa, Josi Khatarina and Rifqi Sjarief Assegaf, 2012:184).

\section{Using Human Rights Instruments For Community Environmntal Disputes.}

Approaching environmental community disputes from the angle of human rights is perceived as urgent, as pollution is borderless and its impact may be transnational. There are several components of the interaction between human rights and the environment. Firstly, sustainable development and the protection of the environment can contribute to human well-being and the enjoyment of human rights. Secondly, environmental damage can have negative implications, both direct and indirect, for the effective enjoyment of human rights. Thirdly, environmental damage is felt most acutely by those segments of the population already in vulnerable situations. Fourthly, environmental damage is transnational in character and that effective international cooperation to address such damage is important in order to support national efforts for the realization of human rights. Finally, human rights obligations and commitments have the potential to inform and strengthen international, regional and national policymaking in the area of environmental protection and promoting policy coherence, legitimacy and sustainable outcomes (General Assembly, Analytical study on the relationship between human rights and the environment, Report of the United Nations High Commissioner for Human Rights, 16 December 2011 (A/HRC/19/34)).

In Indonesia, the nexus of environment to human rights is guaranteed under the 2000 Second Amendment of the 1945 Constitution and protected in the article 
9 Law Number 39 of 1999 on Human Rights and the Article 3 Number 3 of 2009 on EMA. Thus, this connection implies that any violation of environmental rights will be the violation of human rights. Thereby, any community environmental disputes which occurred after the promulgation of the legal instrument of human rights above should have been brought before the Indonesian Human Rights Commission (KOMNAS HAM) for examination. In reality such cases which occurred during the year 1999 were brought before the district courts. Those cases are: The Banger case (1999), Pte Ltd: Sumber Sehat Kudus (1999), Kanasritex (Semarang (1999), Pte Ltd: Kayu Lapis Indonesia (KLI) (1999), Pte Ltd: Pura (Kudus) (1999), Way Seputi River (1999), Tawang Mas (Semarang) (1999), Pekanbaru smog case (1999), Kelian Equatorial Mining, Pte Ltd: Freeport (1999) and the land fire in the OKI district of South Sumatra (2015). Overall, there is very little information whether the parties to the disputes or the victims use other legal remedy, so that the verdicts will meet the expectation of environmental justice of the people.

In the frame of protecting the environmental constitutional rights and environmental legal rights of the people and by referring to human right legal instruments above, there must be a breakthrough to submit the disputes to the Indonesian Commission of Human Rights for examination. Using human rights instruments for environmental community disputes had long time ago been practiced by the European Human Rights Court after the 1972 Stockholm Declaration on Human Environment. Although, in the absent of Environmental provision in the Human Rights Convention, the European Commission of Human Rights (ECHR) has interpreted articles in the Human Rights Convention as provisions close related to environmental rights. The Commission warned that bad environmental conditions could sometimes interfere with the effective enjoyment of the individual's rights and freedoms guaranteed in the Convention. The cases examined by the Commission are Arrondelle v. the United Kingdom (noise) (Application Number 7889/77, Decision of 15 July 1980, DR 19, page 186), G. and Y. v. Norway (Application Number 9415/81, Decision of 3 October 1983, DR 35, page 30), Baggs v. the United Kingdom (noise) (Application Number 9310/81, Decision of 19 January 1985, DR 44, page 13), Powell and Rayner v. the United Kingdom (noise) (Application Number 9310/81, Decision of 16 July 1986, DR 47, page 22), Vearncombe and others $v$. the Federal Republic of Germany (noise) (Application Number 12816/87, Decision of 18 January 1989, DR 59, page 186), X v. France (noise and other inconvenience) (Application Number 13728, Decision of 17 May 1990), Zander v. Sweden (water pollution) (Application Number 14282/88, Decision of 14 October 1992).

At the same time, without any difficulty, the Commission also began to

592 Yustisia Vol. 7 Number 3 (Sept.-Dec. 2018) $\quad$ Juridical Analysis Of The Working ... 
receive individual complaints regarding to restrictions in Convention rights which, according to paragraph 2 of Articles 8 to 11 of the European Convention and Article 1 of Protocol Number 1, pursued a legitimate aim, namely, that of safeguarding good environmental conditions as a general interest (Daniel García San José, 2005: 8). Thus, disputes relating to environment can be submitted by group or by individual. The ECHR practice is actually in contradiction to the fact that right to environment belongs to the third generations of human rights which can only be claimed by a group of people rather than by individual. As a result, the formulation of environmental rights as the third generations of human rights is still subject to political, juridical and doctrinal discussion over several decades until today (F.G. Isa, 11 Human Rights, Pedro Amuge Human Rights Institute, Deusto University (www.humanitariannet.deusto.es/publica/.../International\%20 protect.pdf); Adrian Vasile Cornescu, The Generations of Human Rights, (www. Law mun.cz)). Nevertheless, this practice is a good example for the Indonesian Commission of Human Rights to follow.

From the examples above, pollution and environmental degradation had disrupted the people's daily economy activities. It is rational, therefore, if they seek redress compensation from the angle of civil law. Whereas, the right to economy or the right being free from pollution is the elements of human rights which has been protected by the EMA 2009 and the Law Number 39 of 1999 on The Human Rights. Why do they not refer the human rights instruments as basis for their indictment? This question is hard to answer. Frankly speaking that human rights instrument has been long time ago practiced by the European Court of Human Rights (ECHR), the American Court of Human Rights and the African Court of Human and Peoples' Rights.

Actually the idea to connect environmental rights into human rights instruments derives from Principle 1 of the 1972 Stockholm Declaration which mentions that "Man has the fundamental right to freedom, equality and adequate conditions of life, in an environment of a quality that permits a life of dignity and well-being, and he bears a solemn responsibility to protect and improve the environment for present and future generations..." (A/CONF.48/14/Rev. 1) This principle was restated, albeit differently in Principle 1 of the 1992 Rio Declaration as, "human beings are at the centre of concerns for sustainable development and are entitled to a healthy and productive life in harmony with nature." Herein, sustainable development can be attained if human beings were to live in harmony with the environment. Thus, the fulfillment of human fundamental needs with the quality of the environment relates directly to the full enjoyment of life (R. Desgagne, 1995: 263). As a result, the existence of environmental rights will support human survival (B. D. Ratner, 2004). Some comments from the scholars

\begin{tabular}{ll|l}
\hline Yustisia Vol. 7 Number 3 (Sept.-Dec. 2018) & Juridical Analysis Of The Working ... & 593
\end{tabular} 
such as Hill, Wolfson and Targ (B. Hill et al, 2004: 399-400), and Sumudu Appattu (Sumudu Atapattu, 2002: 65-68) that 'marrying' environmental value to human rights is a slow emergence of the idea that humans have a basic right to a healthy environment. It will however, achieve a higher degree of relevance because the environment is in everyone's backyard (N. A.F. Popovic, 1996: 487). One alludes from the comments above that there is a close connection between environmental rights violation with the impairment of human rights enjoyment (O.C. Ruppel, 'Third-generation of human rights and the protection of the environment in Namibia' (http://scholar.google.com.my/scholar). Human beings in society cannot function independently of the natural environment for no one can escape the human consequence of environmental degradation (N. A.F. Popovic, 'In Pursuit of Environmental Human Rights: Commentary on the Draft Declaration of Principles on Human Rights and the Environment,' page 487). As a result, Giorgetta (N. A.F. Popovic, 'In Pursuit of Environmental Human Rights: Commentary on the Draft Declaration of Principles on Human Rights and the Environment,' page 487) opined that the concept of sustainable development will not be able to be realized if the implementation of such development always impairs the environmental rights.

A similar opinion was articulated by Chen and Dong (C. Demin, and D. Zhengaia, 2008: 189-192) who discussed environmental rights from the perspective of development without impairing the environment. This is the concept of eco-development which principally believes that environmental rights might become the savior and defender of human rights which would ultimately facilitate the production of better conditions of life on earth by stretching and expanding the theory of traditional human rights. The nexus of environmental rights into human rights is quite important for the present and future generation (Fatma Zohra Kesetini's report entitled "Review of Further Developments in the Fields of Human Rights and the Environment" submitted to the 46 th session of the Commission on Human Rights, Sub-Commission on Prevention of Discrimination and Protection of Minorities (between year 1992 and 2001)) for it will foster global awareness of complex, serious and multidimensional nature of environmental problems (Mohammed Sahnoun, "Environnement et développement", Revue algérienne des relations internationales, Number 8, 1987, OPU, Algies in: Mrs. Fatma Zohra Kesentini Report in E/CN.4/Sub.2/1994/9 6 July 1994).

The issue that remains is how one can ensure the nexus with environmental human rights is turned into reality. This is especially important in relation to the impact of environmental rights violation on human rights and vice versa as well as how to utilize the human rights mechanisms to address environmental 
violation. For that, according to Galpe and Tarlock (M. Galpe and A. D. Tarlock, 1974: 371), this can be done by measuring the degree of the impact when such activities are allowed and when such a project should be prohibited or modified required scientific involvement verification. Thus, there are a number of parameters involved in determining the negative impact of such development on the environment. In the case of land fire in the OKI district of South Sumatra the impact of the pollution can be traced though the number of people who suffers from respiratory diseases that are recorded in the community health centre in the affected areas. Herein, the people's right to life as protected by Law Number 39 of 1999 on the Human Rights has been impaired. Nevertheless, other people's rights also infringed. The people cannot do their daily economic activities. Meaning the right to economy has been disrupted. The students and the pupils cannot go to university and schools. Meaning the right to education has been disturbed. Thus, land fire in the case above has violated a number of people's rights as protected by the EMA 2009 and Human Rights Law. Environmental rights are constitutional rights guaranteed in the 2000 Second Amendment of the 1945 Constitution. Derives from the human rights instruments above, community environmental disputes can be submitted to the Indonesian Commission of Human Rights (KOMNAS HAM) for further examination.

\section{Indonesian Commission Of Human Rights}

The legal foundation of the National Commission of Human Rights is Chapter VII of the Law Number 39 of 1999 on Human Rights which deals with the National Commission of Human Rights (KOMNAS HAM). The rights and duties and the functions of the KOMNAS HAM is regulated in articles 75-99. Herein, anyone or group of people who have reason to believe that their human rights have been violated may file a complaint report orally or in written to the Human Rights Commission. In the case of complaints submitted by other parties, the complaint must be accompanied with the approval of the party whose rights have been violated. Herein, the 1999 Law Number 39 mentions that human rights violations complain may be filed through representation. Further, the National Commission of Human Rights should investigate and examine the allegation of human rights violation. As such, any violation to the protected human rights related to environment can be submitted to the National Commission of Human Rights for further examination.

Theoretically one can say that human rights court is the rights place for those who seek justice for their human rights violation. Article 9 Paragraph 3 of the Law Number 39 of 1999 Human Rights, Article 3 of the EMA 2009 and

\begin{tabular}{ll|l}
\hline Yustisia Vol. 7 Number 3 (Sept.-Dec. 2018) & Juridical Analysis Of The Working ... & 595
\end{tabular} 
Article $28(\mathrm{H})$ of the 1945 Constitution are the legal foundation of the charge. Unfortunately, the jurisdiction of Human Rights Court has been restricted by the 2000 Law Number 26 on Human Rights Court which only deals with crime of genocide and crime against humanity. These two categories of crimes are classified as serious human rights violation. Meanwhile, environmental crime or environmental rights violation is not under the jurisdiction of Human Rights Court. As a result the case is considered to be as common violation to which the district court is the right place for adjudication.

\section{E. CLOSING}

Community environmental dispute is very distinctive compared to other dispute in law. The complexity of the elements involved the environment covers aspects of economy, politics, social, and law. The biotic and a-biotic elements are physical feature of the environment make the district court judge is not very keen in providing the decision which is in accordance with environmental justice of the people. This can be seen in many community environmental disputes.

Although people's environmental rights is constitutional rights and protected by the Law Number 39 of 1999 on The Human rights and the Law Number 32 of 2009 on The Environmental Management. It does not automatically means that the community environmental dispute-related human rights can be filed to Human Rights Court for adjudication. Community environmental dispute is not inline to the Law Number 26 of 2000 on Human Rights Court. The Human Rights Court is granted mandate to only hear serious human rights violation case which include in the category of genocide crime and crime against humanity.

Since environmental pollution and environmental degradation disrupt the people's enjoyment to human rights, such as the right to life, the right to economy, the right to education, health, prosperity and so forth and by referring to the objectives and the functions of the National Commission of Human Rights has to accept the people's application for further examination. Using human rights instruments for the community environmental dispute is the way to protect the people's environmental rights. 


\section{BIBLIOGRAPHY:}

\section{Books:}

Amsyari, Fuad, 1976, Prinsip-Prinsip Masalah Pencemaran Lingkungan (Principles of The Environmental Defilement Problems), Ghalia.

Danusaputro, Muandjad, 1981, Hukum Lingkungan (Environmental Law), Buku II: National, Binacipta: Bandung,.

F.C. Evans, 1969, Ecosystem as a Basic Unit in Ecology.

G. San José, 2005, Environmental protection and the European Convention on Human Rights, Council of Europe Publishing.

Mas Achmad Santosa, Josi Khatarina and Rifqi Sjarief Assegaf, 2012, Introduction: climate change risk, sources and government policies and measures, in R. Lord et al, (Ed)., Climate Change Liability: Transnational Law and Practice, Cambridge University Press,.

Romsan, Achmad CS, 1990, Deforestation in the Sub-District of Tulung Selapan, research Report, Research Institute: Sriwijaya University,. 2000, Massive Forest Fire in South Sumatra toward the Fall of

Suharto in 1998. Research Report, Research Institute: University of Sriwijaya. , 2015, Environmental Human Rights: Problems of Implementation in Indonesia, $\mathrm{PhD}$ thesis: Universiti Kebangsaan Malaysia,

Soemantri, Hardja, 1983, Hukum Tata Lingkungan (Law of The Environmental Governance), Penerbit UGM: Yogyakarta.

\section{Journals:}

B. D. Ratner, 'Environmental Rights is a Matter of Survival'(Spring) (2004) 2 (11) Human Rights Dialogue.

Hill et al, 'Human Rights and the Environment: A Synopsis and Some Predictions,' (2004) 16 (359) Geo. Int'l Envtl. L. Rev.

Demin, and D. Zhengaia, 'Environmental rights: on the perspective of harmonious development between human beings and nature', Law School of Chongqing University, Chongqing 400044, China (2008) 18 (1) China Population, Resources and Environment.

M. Galpe and A. D. Tarlock, 'The Use of Scientific Information in Environmental Decision Making,' (1974), 48 So.Cal.L.Rev.

N. A.F. Popovic, 'In Pursuit of Environmental Human Rights: Commentary on the Draft Declaration of Principles on Human Rights and the Environment.' (1996) 27 Colum. Human Rights L. Rev.

Yustisia Vol. 7 Number 3 (Sept.-Dec. 2018) Juridical Analysis Of The Working ... 
O.C. Ruppel, 'Third-generation of human rights and the protection of the environment in Namibia' (http://scholar.google.com.my/scholar)

R. Desgagne, 'Integrating environmental values into the European Human Rights Convention.' The American Society of International Law, (1995) 89 A.J.I.L. 263.

S. Giorgetta, 2002, The Right to A good and Healthy Environment, International Environmental Agreements: Politics, Law and Economic.

Sumudu Atapattu, "The Right to a Healthy Life or the Right to Die Polluted?, The Emergence of a Human Rights to a Healthy Environment Under International Law, (2002) 16 Tul. Envil. L. J.

\section{Reports:}

Fatma Zohra Kesetini's report entitled "Review of Further Developments in the Fields of Human Rights and the Environment" submitted to the 46 th session of the Commission on Human Rights, Sub-Commission on Prevention of Discrimination and Protection of Minorities (between year 1992 and 2001).

Achmad Romsan, Massive Forest Fire in South Sumatra toward the Fall of Suharto in 1998. Research Report in collaboration with Forest Fire Project funded by European Union in cooperation with the Department of Forestry of South Sumatra.

Friends of the Earth International, Lapindo Brantas and the Mud Volcano Sidoarjo, Indonesia, A background paper prepared for Friends of the Earth International and Friends of the Earth Europe, June 15, 2007

Mohammed Sahnoun, "Environnement et développement", Revue algérienne des relations internationales, Number 8, 1987, OPU, Algies in: Mrs. Fatma Zohra Kesentini Report in E/CN.4/Sub.2/1994/9 6 July 1994.

Report of the United Nations High Commissioner for Human Rights, 16 December 2011 (A/HRC/19/34).

\section{Internet:}

A. V. Cornescu, The Generations of Human Rights, www. Law mun.cz.

F.G. Isa, 11 Human Rights, Pedro Amuge Human Rights Institute, Deusto University, www.humanitariannet.deusto.es/publica/.../International\%20protect.pdf.

http://www.dw.com/jd/penyebab-kebkran-hutan-terungkap/a-18801135.

http://www.minesandcommunities.org/article.php?a=1344.

598 Yustisia Vol. 7 Number 3 (Sept.-Dec. 2018) $\quad$ Juridical Analysis Of The Working ... 


\section{Regulations:}

The 1945 Constitution of the Republic of Indonesia

The 1999 Law Number 39 on Human Rights (State Gazette of The Republic of Indonesia Number 165 of 1999)

The 2009 Law Number 32 on the Protection of and the Management of the Environment

(State Gazette of The Republic of Indonesia Number 140 of 2009)

The 2000 Law Number 26 on Human Rights Court (State Gazette of The

Republic of Indonesia Number 208 of 2000)

\section{National Cases:}

Lapindo Brantas, Limited Liability Comppany v. WALHI (2007) (Verdict Number 284/Pdt.G/2007/PN. Jak. Sel.)

Minister for Environment v. PTE LTD. Bumi Mekar Hijau Decision Number 24/ Pdt.G/2015/PN.Plg.

\section{International cases:}

Pine Valley Development Ltd and others v. Ireland (Application Number 12742/87, Decision of admissibility of 3 May 1989).

Arrondelle v. the United Kingdom (noise) (Application Number 7889/77, Decision of 15 July 1980, DR 19)

G. and Y. v. Norway (Application Number 9415/81, Decision of 3 October 1983, DR 35),

Baggs v. the United Kingdom (noise) (Application Number 9310/81, Decision of 19 January 1985, DR 44).

Powell and Rayner v. the United Kingdom (noise) (Application Number 9310/81, Decision of 16 July 1986, DR 47) (Application Number 12816/87, Decision of 18 January 1989, DR 59, p. 186).

Vearncombe and others v. the Federal Republic of Germany (noise) (Application Number 12816/87, Decision of 18 January 1989, DR 59).

$X$ v. France (noise and other inconvenience) (Application Number 9310/81, Decision of 16 July 1986, DR 47).

Zander v. Sweden (water pollution) (Application Number 14282/88, Decision of 14 October 1992).

\begin{tabular}{ll|l}
\hline Yustisia Vol. 7 Number 3 (Sept.-Dec. 2018) Juridical Analysis Of The Working ... & 599
\end{tabular} 